\title{
Fernando VII contra los periodistas. Los procesos seguidos por la Comisión de Causas de Estado*
}

\author{
Beatriz Sánchez Hita ${ }^{1}$ \\ Universidad de Cádiz \\ beatriz.sanchez@uca.es
}

RESUMEN: En el siguiente estudio se analizan los documentos relativos a procesos contra editores y periodistas conservados en la Comisión de Causas de Estado del Archivo Histórico Nacional (Madrid, España). A través de dichos expedientes puede dibujarse cómo se produjo la persecución de aquellos que habian tratado de crear una opinión pública favorable al régimen constitucional durante la época de las Cortes tras la reinstauración del absolutismo, qué aspectos fueron los que más ofendieron a Fernando VII y cómo los encausados articularon sus defensas para lograr ser sancionados con la menor pena posible.

\section{Palabras clave: Fernando VII; Comisión de Causas de Estado; pe- riodismo; liberalismo; absolutismo; represión.}

\section{FernandoVII against the journalists. Litigations by the State Lawsuit Commission}

ABSTRACT: This paper deals with the documents associated to the litigations against editors and journalists stored in the State Lawsuit Commission (Madrid, Spain). These files illustrate the persecution of those who tried to create a pro-constitutional public opinion, the aspects which were received as important affronts by Fernando VII and the defendants' strategies to be penalized as less as possible.

* Este trabajo forma parte de los resultados de investigación del Proyecto de Investigación financiado por el Ministerio de Economía, Industria y Competitividad: «La cultura literaria de los exilios españoles en la primera mitad del siglo XIX (CLEX19)» (Referencia: FFI201340584-P). Se emplean las siguientes abreviaturas: Archivo Histórico Nacional de España: (AHN) y Archivo General Militar de Segovia: (AGMS).

1 ORCID iD: http://orcid.org/0000-0003-4618-8769. 
KEY WORDS: Ferdinand VII King of Spain; State Lawsuit Commission; Journalism; Liberalism; Absolutism; Repression.

CÓMO CITAR ESTE ARTÍCULO/CITATION: Sánchez Hita, Beatriz, «Fernando VII contra los periodistas. Los procesos seguidos por la Comisión de Causas de Estado», Hispania, 77/256 (Madrid, 2017): 375-405. doi: 103989/hispania.2017.011.

Con el Real Decreto de 4 de mayo de 1814 Fernando VII abolía y declaraba sin ningún valor la obra de las Cortes y la Constitución en un intento de borrar así el pasado político inmediato «como si no hubiesen pasado jamás tales actos $\iota^{2}$. Se materializaba con ello un verdadero golpe de Estado, cuyo éxito se debió a la imagen del rey difundida al pueblo y a la permisividad exterior ${ }^{3}$.

El Deseado no iba a convertirse en rey constitucional y pronto comenzaría una escrupulosa represión contra aquellos que habían sido los artífices y promotores de un nuevo régimen político que pretendía superar el absolutismo: los liberales. Para ello, además del restablecimiento de los antiguos tribunales - incluida la Inquisición_-, se crearían diversos organismos que trataron de satisfacer el deseo de revancha que movía al recién retornado Fernando VII. Para ello, el 16 de mayo de 1814 por Real Decreto se creaba la Comisión de Policía, cuya finalidad era la de perseguir a cuantos hubiesen podido atentar contra la soberanía del Rey; sin embargo la cantidad de documentos a revisar (Diario de las Cortes, actas, periódicos...), así como las diligencias que era necesario practicar, hicieron imposible que en un corto plazo se pudiesen concluir con garantías los trabajos y los miembros de la comisión renunciaron a sus cometidos. La consecuencia directa fue la creación el 14 de septiembre de la Comisión de Causas de Estado, que aunque se dedicó a revisar la acción de diputados y exrregentes ${ }^{4}$, extendió sus procedimientos a otros sujetos marcados por su adhesión a la causa constitucional, entre los que se encontraban no pocos periodistas. Esta nueva comisión tampoco logró satisfacer con celeridad las ansias de venganza del monarca, que acabó por condenar a cincuenta y un encausados el 15 de diciembre de 1815, disolviendo la Comisión el 26 de enero de $1816^{5}$.

En el presente estudio se analizarán los documentos relativos a prensa conservados en los papeles de la Comisión de Causas de Estado custodiados en el

2 Real Decreto de Fernando VII derogando la Constitución, 1814: (8). En la Gaceta de Madrid número 70 (12-V-1814) se incluía este decreto; en los ejemplares siguientes de la citada publicación oficial pueden rastrearse las diferentes medidas adoptadas por el monarca para restablecer tribunales e iniciar la represión, al tiempo que se ofrecen noticias sobre las celebraciones realizadas en los diferentes puntos del país para festejar la vuelta del rey.

3 LA PARRA LÓPEZ, 15, Oviedo, 2014: 210.

4 ÁLVAREZ-COCA, 37, Madrid, 2012: 238.

5 Los procesos pasaron entonces a tribunales ordinarios. 
Archivo Histórico Nacional de España, que por el momento son los únicos que aportan datos sobre este aspecto ${ }^{6}$. Nos interesaremos aquí no solo por el resultado de las sentencias ${ }^{7}$, sino por el contenido de los procesos en sí, ya que a partir de este puede dibujarse el funcionamiento de muchos de los periódicos estampados en la época y las relaciones existentes entre cabeceras, al tiempo que es posible saber qué actuaciones fueron las que se persiguieron y castigaron tras la vuelta de Fernando VII, o qué papel jugaron impresores y libreros en la represión de sus otrora clientes. Se tratará, en definitiva, de reconstruir a través de una no muy conocida documentación qué supuso la vuelta al absolutismo para aquellos que con palabras habían intentado sustentar el cambio político.

\section{Procesos CONTRA EDITORES Y PERIODISTAS CONSERVAdOS EN LA COMI- SIÓN DE CAUSAS DE ESTADO DEL ARCHIVO HISTÓRICO NACIONAL}

De entre el conjunto de expedientes de la Comisión de Causas de Estado hay varios en los que el objetivo de las indagaciones fueron los editores y equipos de redacción de señeros periódicos liberales, estampados en Cádiz y

6 Los papeles de la Comisión de Causas de Estado se conservan en el Archivo Histórico Nacional en Consejos, legajos 6289 a 6314 y Diversos-Colecciones, legajos 117 a 119; y se completan en parte con los «Papeles reservados de Fernando VII» del Archivo del Congreso de los Diputados, Madrid, tal y como indica ÁLVAREZ-COCA, 37, Madrid, 2012: 238, n. 148. A estos últimos habría que añadir los legajos de dichos papeles que se conservan en el Archivo General de Palacio, Madrid. Sobre los contenidos de la última serie citada, y en concreto para los custodiados en el Congreso de los Diputados, véase RODRÍGUEZ CASTILLO 23/1, Madrid, 2013: 203-238 quien analiza los 108 tomos que integran aquella colección, sin que se aprecien en el extracto datos relevantes para el estudio de la prensa. Igualmente conviene precisar que los índices de los papeles reservados en el Archivo General de Palacio tampoco reflejan que en los legajos allí conservados se hallen noticias sobre las causas seguidas contra editores y periodistas. A estos expedientes consultados en los archivos citados debe añadirse para completar la información que aquí nos interesa el Decreto de 15 de diciembre de 1815 recogido durante el Trienio Liberal en las páginas del Diario Gaditano (15-IX-1820/31XII-1822) al final de los siguientes números: 152 (13-II-1821), 154 (15-II-1821), 156-158 (17/19-II-1821) y concluye en 164 (25-II-1821).

7 Las sentencias dadas por la Comisión de Causas de Estado se comercializaron como folletos -9 en total - tirados desde la Imprenta Real y se anunciaron en la Gaceta de Madrid 22-X-1814, 5-XI-1814, 8-XI-1814, 13-XII-1814, 11-II-1815, 20-VII-1815 y 21-IX-1815, según indica FERNÁNDEZ MARÍN, 1900: 195; estos pueden consultarse en http://dspace. ceu.es/handle $/ 10637 / 3561$ ? mode=full\&empezar=1. Dichos documentos se publicaron parcialmente, en concreto hasta la causa formada a Laureano Antonio Escamilla - página 39 de la compilación citada y consultable en red-, en El Procurador General del Rey y de la Nación en los días 9-13 de noviembre y 15-16 de diciembre de 1814 y 12-14 de febrero y 13-14 de abril de 1815. Las minutas originales se localizan en Expediente general de la Comisión de Causas de Estado, AHN, Consejos, legajo 6298, exp. 5. 
Madrid principalmente cuando en dichas ciudades estuvieron instaladas las Cortes o se preparaba su instalación ${ }^{8}$. Entre estos se encuentran los procesos del Semanario Patriótico (Madrid, 1-IX/24-XI-1808; Sevilla, 4-V/31-VIII1809 y Cádiz, 22-XI-1810/19-III-1812) ${ }^{9}$, El Redactor General (Cádiz, 15-VI1811/18-V-1814), El Tribuno del Pueblo Español (Cádiz, 3-XI-1812/5-XI1813 y Madrid, 1-II/1-IV-1814), así como las causas parciales que acabarán derivando en un análisis del conjunto de los contenidos de El Ciudadano (Madrid, 1-VII/29-X-1813) y El Universal (Madrid, 1-I/11-V-1814) ${ }^{10}$.

\section{El Semanario Patriótico (Madrid, 1-IX/24-XI-1808; Sevilla, 4-V/31- VIII-1809 y Cádiz, 22-XI-1810/19-III-1812) y sus redactores}

El 10 de mayo de 1814 Manuel José Quintana era conducido al cuartel de Guardias de Corps; se iniciaba así un largo arresto durante el que su conducta

8 No se incluye aquí la caracterización de cada uno de los periódicos; puede verse para los títulos gaditanos SÁNCHEZ HITA, 2008 y para el conjunto de cabeceras CHECA GODOY, 2009 y GIL NOVALES, 2009.

9 Las investigaciones sobre Semanario Patriótico se vinculan a la causa seguida contra Manuel José Quintana. Uno de los primeros diputados liberales apresados y que tras Bartolomé José Gallardo encabezaba el listado dado el 4 de mayo, por el que se precisaba quiénes debían ser arrestados de manera inmediata para examinar su conducta política. Dicho listado puede leerse en VILLANUEVA, 1820: 456-457 y se custodia en Sumaria general de las causas de Estado instruidas por el juez comisionado Manuel José Rubio, contra varios diputados de las Cortes de Cádiz, por los abusos cometidos en el ejercicio de dicho cargo, AHN, Consejos, legajo 6311, exp. 1, f. 2r-v.

10 En lo que se refiere a los equipos de El Ciudadano y El Universal las causas se inician a partir de procesos por el contenido del primer número y del número ciento veintiséis, respectivamente. No se incluye aquí la investigación no concluida sobre la retirada de la Atalaya de La Mancha ordenada por la Junta de Censura de Cádiz en 1813 y que está integrada por el proceso seguido por la citada Junta contra el número 8 de la publicación donde su editor, fray Agustín de Castro, criticaba el primer ejemplar de El Ciudadano. De lo dicho por De Castro, la Junta extrapola que trataba de fomentar la subversión al defender los poderes absolutos de Fernando VII, esto llevó a la recogida del periódico y al arresto domiciliario del responsable. Los documentos, conservados en Causa de estado relativa a la retirada del periódico conocido como «La Atalaya de la Mancha» ordenada por la Junta de Censura, AHN, Consejos, legajo 6301, exp. 3, son en su mayor parte anteriores a la creación de la Comisión de Causas de Estado; el hecho de que el expediente fuese recuperado por la Comisión tiene que ver, probablemente, con la revisión que luego hará sobre la actuación de la Junta de Censura durante la Guerra de la Independencia, cuando se analiza su diferente actuación ante contenidos conservadores y liberales. Los documentos del proceso a la Junta se localizan en Causa de Estado instruida contra Manuel Padilla, José Rice-Osorio. Juan Bautista Elejaburu, Rafael María Garaycoechea, Francisco Fernández del Castillo y Manuel María Urquinaona, todos ellos miembros de la Junta de Censura de Cádiz, por su actuación laxa en el desempeño de sus funciones, AHN, Consejos, legajo 6297, exp. 2bis. 
política y su producción iban a ser analizados, prestándose especial atención al Semanario Patriótico ${ }^{11}$. El 15 de mayo se le comunicaban al reo los motivos de su reclusión y se iniciaban los trámites para la inspección de su vivienda, realizada los días 18 y 23 de mayo con Domingo Benito Quintana como testigo.

Los datos recabados a partir de los registros constituyen la base de los interrogatorios realizados a Quintana los días 21 y 23 de junio. Una de las primeras cuestiones que se le realizan tiene que ver con la autoría del Semanario Patriótico, del que manifiesta haber estado al frente en su primera y tercera época; en las que lo acompañaron Eugenio de Tapia y Joaquín Abaitúa en la primera, y José Álvarez Guerra, Eugenio de Tapia y José Rebollo en la tercera, en la que actuó como autor y editor; indica asimismo que en la segunda época, la sevillana, los responsables fueron José María Blanco White e Isidoro Antillón. Respecto a la misión del impreso dirá que con él se propuso:

mantener el espíritu público en la Guerra que tenía la patria contra los franceses y, al mismo tiempo, ilustrar la opinión según los alcances de los autores para que se hiciesen en la Administración y el Gobierno aquellas reformas necesarias para precaver los males tan horribles adonde la arbitrariedad de los tiempos pasados habían conducido a la nación ${ }^{12}$.

Más adelante es preguntado por los contenidos del hebdomadario, pues se trata de averiguar si contenía especies contrarias a la soberanía de Su Majestad, ante lo que Quintana responde presentando el Semanario como hijo de su tiempo - acorde por tanto a las leyes de 1810 a 1812 - y manifiesta su respeto a la actual situación política:

en este papel podría haber alguna especie consecuente con la soberanía declarada por las Cortes de la nación, pero que estas especies no pasaban en dicho papel de meras opiniones manifestadas en un tiempo en que la ley daba esta facultad, y que no sirven de impedimento para reconocer y obedecer la soberanía declarada por S. M. en su persona como reconoce y obedece ${ }^{13}$.

11 Sobre los pormenores de su arresto y estancia en prisión puede verse su Memoria del Cádiz de las Cortes en la edición de DURÁN LÓPEZ, 2003. Si se revisa el contenido de la Memoria a la luz del expediente del proceso se aprecia que Quintana fue bastante fiel a los hechos vividos al trasladarlos por escrito. La firmeza en la posición del encausado que denota la Memoria, tal y como apunta DURÁN LÓPEZ, 2003: 20, queda reflejada con claridad en las declaraciones que da en la causa y los juicios de valor sobre la seriedad con la que se escribía el periódico y su tono menos exaltado que el de otros (DURÁN LÓPEZ, 2003: 151 y 192).

12 Expediente formado por la Comisión de Causas de Estado a Manuel José Quintana, José Rebollo y Eugenio de Tapia, por delitos contra la nación y la soberanía del Rey, AHN, Diversos-Colecciones, legajo 118, $\mathrm{n}^{\circ} 2, \mathrm{f}$. 12r.

13 Expediente formado por la Comisión de Causas de Estado a Manuel José Quintana..., AHN, Diversos-Colecciones, legajo 118, nº 2, f. 13r. 
Tras la declaración de Quintana, se incluye en el procedimiento al resto del equipo y el 23 de julio se pide que se registren las casas de Juan Álvarez Guerra, Eugenio de Tapia, José Rebollo y Joaquín Abaitúa en busca de una colección del Semanario - que no consiguen aportar los dos primeros, por la premura con la que dicen haber partido de Cádiz a Madrid - ${ }^{14}$ y se pide que sean interrogados. El 2 de agosto declara José Rebollo y al día siguiente Eugenio de Tapia, que reafirman lo dicho por Quintana sobre el cometido del periódico, siendo significativas las palabras de Tapia que aprovecha la ocasión para adular a Fernando VII, al decir que los objetivos fueron «fomentar el odio contra los franceses y el amor y adhesión a nuestro amado soberano el Señor Don Fernando VII» ${ }^{15}$. Al ser preguntados por los demás redactores: Abaitúa, Blanco y Lista, dirán que se rumorea que el primero partió con los franceses, como ya hizo Lista en Sevilla y que Blanco se encuentra instalado en Inglaterra.

A partir de sus palabras y después de revisar los cuadernos de la primera y tercera época del periódico se determina que, si se contrasta con otros papeles publicados en la época de las Cortes como la Abeja, El Redactor o El Duende de los Cafés, el Semanario resulta más moderado. Se indica también que su cese una vez promulgada la Constitución es una prueba de que los editores no tenían perversas miras, a lo que se suma el que hayan reconocido a Fernando VII como legítimo soberano una vez sancionada por las Cortes la soberanía nacional, para lo que se extrae como prueba un párrafo del no $57(9-\mathrm{V}-1811)$ y otro del $\mathrm{n}^{\mathrm{o}} 75$ (12-IX-1811):

[...] volviendo su arrebatado enojo contra los numerosos invasores, no descansó un momento hasta arrojarla de la Corte del legítimo soberano, teatro de horrorosas y sangrientas escenas [...]

[...] Independencia, Religión Católica, Monarquía, Fernando VII y buen gobierno son los votos universales de los españoles ${ }^{16}$.

Estas palabras propician que el 22 de agosto de 1814 se levante el arresto a Tapia y a Rebollo ${ }^{17}$, mientras que a Quintana se le forma causa separada, pues

14 Expediente formado por la Comisión de Causas de Estado a Manuel José Quintana..., AHN, Diversos-Colecciones, legajo118, no 2, ff. 36v-37r.

15 Expediente formado por la Comisión de Causas de Estado a Manuel José Quintana..., AHN, Diversos-Colecciones, legajo118, $n^{\circ}$ 2, f. 40r-49r.

16 Expediente formado por la Comisión de Causas de Estado a Manuel José Quintana..., AHN, Diversos-Colecciones, legajo118, $n^{\circ}$ 2, ff. 61v-62v.

17 El 20 de noviembre de 1814 Tapia vuelve a ser apresado y juzgado, en este caso por el Tribunal de la Inquisición, como consecuencia de la acusación de conspirador contra el altar y el trono hecha por Vicente Lema. Tras varios meses y habiendo visto morir a su hijo de tres años en la cárcel resultó absuelto el 9 de agosto de 1815. Sobre estos hechos véanse los documentos custodiados en Uguina, Antonio; Osorno, Feliciana; Osorno, Catalina; Tapia, Eugenio; Rebollo, José; Balbuena, Manuel; Pereira, José Joaquín; Díaz, José de María; Mendi- 
se siguen considerando graves sus actuaciones y las exposiciones de algunos testigos lo vinculan con los sectores liberales más activos de la tribuna de las Cortes y los cafés Apolo y Patriotas. Lo mismo sucede con Juan Álvarez Guerra, que desde mayo se encontraba preso en el Cuartel de Guardias de Corps y que se juzgaba por abusos en su empleo como Secretario del Despacho de Gobernación, vínculos con los liberales, participación en el Semanario y escritura de obras políticas.

El mencionado proceso contra Álvarez Guerra casi reabre la causa contra el Semanario, pues en las preguntas que se le dirigen el 7 de noviembre de 1814 queda patente que el impreso fue un importante pilar para las nuevas instituciones y que impulsó el nuevo orden político ${ }^{18}$. A lo que se añaden las palabras de Francisco José de Molle, que el 9 de febrero amplía las declaraciones realizadas al inicio de las causas en Cádiz, y añade respecto al Semanario que este fue el «primer papel que empezó a extraviar la opinión pública en España» por no respetar las antiguas instituciones, atacar la Inquisición y hacer la «guerra al Clero y a la Nobleza, clases del Estado que incomodaban sus ideas democráticas ${ }^{19}$.

Pese a todo el 15 de abril el fiscal indica que su opinión respecto al periódico es la misma que en agosto; se mantiene la situación de Rebollo y Tapia, que deberán satisfacer los costes mancomunados del proceso con Quintana y Alvarez Guerra, quienes además correrán con su parte en los otros que tienen abiertos. Más tarde, a los dos primeros se les impone el 2 de diciembre de 1815 una multa de quinientos ducados ${ }^{20}$.

En el caso de Juan Álvarez Guerra, el 21 de noviembre de 1815 llega a establecerse para él una pena «de seis años de destierro de Madrid y Sitios Reales 20 leguas en contorno», que se interpretó como reclusión en Zafra - de donde era natural- y su término ${ }^{21}$, pero Fernando VII no se conforma con ella y lo condena mediante el Decreto de 15 de diciembre de 1815 a ocho años de destierro en Ceuta, sin que cumplidos pueda pasar a Madrid y sitios reales sin su permiso; por su parte Quintana es sancionado con seis años de

nueta, Hilario; San Román, Pascual y Uguina, Antonio; Osorno, Feliciana; Osorno, Catalina; Tapia, Eugenio AHN, Inquisición, legajo 3722, exp. 216, 1 y 2; Tapia, Eugenio y Monasterio, María Jesús, Inquisición, legajo 3727, exp. 67.

18 Expediente formado por la Comisión de Causas de Estado a Juan Álvarez Guerra, secretario de la Gobernación durante la guerra, por delitos contra la nación y la soberanía del Rey, AHN, Diversos-Colecciones, legajo117, n 2, ff. 89v-93v.

19 Expediente formado por la Comisión de Causas de Estado a Juan Álvarez Guerra..., AHN, Diversos-Colecciones, legajo117, n 2, f. 214r-v.

20 Expediente formado por la Comisión de Causas de Estado a Juan Álvarez Guerra..., AHN, Diversos-Colecciones, legajo117, no 2, ff. 222r-229v y 236r-v.

21 Expediente formado por la Comisión de Causas de Estado a Juan Álvarez Guerra..., AHN, Diversos-Colecciones, legajo117, $\mathrm{n}^{\circ}$ 2, f. 5v., segundo ramo. 
reclusión en la ciudad de Pamplona y la privación de sus empleos, según se recoge en el Diario Gaditano, no 157 , (18-II-1821) y n ${ }^{\circ} 158$, (19-II-1821).

El 17 de enero de 1816 se establecen finalmente los costes del proceso, que deben abonar todos los afectados mancomunadamente ${ }^{22}$. Desde entonces se esforzarán por encontrar la forma de aportar el dinero reclamado, no siempre con éxito.

\section{El Redactor General (Cádiz, 15-VI-1811/18-V-1814)}

La causa contra este periódico es una de las más completas de las conservadas en los papeles de la Comisión de Causas de Estado, lo que permite además de seguir el juicio a sus redactores -Pedro José Daza (principal responsable y dueño de la imprenta desde la que se publicaba), José Joaquín de Sagarzurieta, José Manuel Fernández de los Senderos y Manuel de Alzáibar-, conocer cómo se organizaba el trabajo de edición de un periódico de notable importancia ${ }^{23}$.

El proceso se inicia con una real orden dada el 27 de junio de 1814 por la que se pide que se arreste a Daza, que el 8 de julio es recluido en el Castillo de Santa Catalina. En los exámenes a los que se le somete intenta demostrar que siempre actuó en defensa de Fernando VII; lo que avala con hechos heroicos pasados como la redacción de un plan que permitió salvar a veinte mil españoles en 1808, su labor como intérprete en el destacamento de artillería de Cádiz, su contribución a la guerra con un donativo de 180 reales de vellón mensuales o su aportación para conseguir una vacuna en mayo de 1814 para paliar la epidemia de la ciudad, y también con textos concretos publicados en El Mercurio Gaditano en los que celebra el retorno del monarca, como el aparecido en el no 19 (6-VI-1814) 24 . Todos estos méritos y el hecho de encargarse de la corrección de pruebas y de secciones no muy comprometidas del periódico hicieron que acabase por decretarse su libertad el 8 de noviembre de 1815 , estableciéndose como pena, junto al tiempo cumplido en prisión, el pago de dos mil duros.

22 Expediente formado por la Comisión de Causas de Estado a Manuel José Quintana..., AHN, Diversos-Colecciones, legajo118, $\mathrm{n}^{\circ}$ 2, f. 71r-v.

23 Puntualmente colaboraron además de los mencionados José Redondo, Julián Villalba y posiblemente Juan Corradi — redactor del Diario de las Cortes - en los extractos de lo acaecido en las Cortes. Sobre este aspecto y el funcionamiento del periódico remitimos a SÁNCHEZ HITA, 16 (Cádiz, 2010).

24 Causa de Estado instruida contra Pedro José Daza, José Manuel Fernández de los Senderos, José Joaquín de Sagarzurieta, Manuel de Alzaibar y Bernabé García, editores y colaboradores del periódico «El Redactor General» de Cádiz, AHN, Consejos, legajo 6294, exp. 1, f. 304r-314v y segundo ramo, ff. 50v y 51r. Véase igualmente la transcripción de la sentencia en SÁNCHEZ HITA, 2010: 43-49 y SÁNCHEZ HITA, 13, Aix-en-Provence, 2016. 
José Joaquín Sagarzurieta, cuya participación en la empresa empieza en agosto de 1813, pudo probar que su labor fue similar a la del propio Daza, ya que se encargaba de la corrección de pruebas de imprenta, de traducir los periódicos ingleses y extractar los de Madrid, Cataluña y Cádiz. Eso hizo que no fuese recluido en prisión, pero sí obligado a permanecer en Cádiz y que acabase condenado a pagar una multa de quinientos duros.

Ahora bien, como debían pagar las costas del proceso general, en diciembre de 1815 Daza y Sagarzurieta siguen sin disfrutar de su libertad, pese a haber satisfecho las multas, de lo que se queja Lázaro de Soto, abogado de ambos en las apelaciones al proceso ${ }^{25}$.

La suerte corrida por los otros dos responsables del papel fue más adversa. En lo que respecta a Senderos, reclamado el 15 de septiembre e interrogado los días 23 y 24 de octubre, cuando fue localizado, este pudo probar que pese a realizar el extracto de los periódicos de Cádiz no se encargaba de los resúmenes más comprometidos que eran los de El Procurador General por las críticas a sus contenidos que se solían verter en ellos, la Abeja Española y los Duendes de los que diría que generalmente se hacía cargo Alzáibar —en el caso de la Abeja por ser uno de sus editores-. Esto hacía previsible que recibiese una pena similar a los otros, pero debido al proceso ejecutado contra él y Juan José de Iriarte por ofender en un texto a las Guardias Reales, Senderos es condenado en noviembre de 1814 a «ocho años de presidio en el del Peñón y [...] mil duros de multa» ${ }^{26}$, lo que hizo que optase por huir y con la fuga la pena subiría a diez años de arresto en el Peñón ${ }^{27}$.

Los testimonios aportados por los redactores hasta aquí dejaban ver que era Alzáibar quien había elaborado los textos más osados y que además era coeditor de otro de los papeles públicos cuyos contenidos situaron a sus responsables en el punto de mira de la Comisión de Causas de Estado: la Abeja Española; quizá por ello permaneció largo tiempo huido y, solo cuando se había calmado la situación de represión inicial, a través de María Brígida de la Puente, su mujer, que desde agosto de 1816 hasta diciembre de 1817 dirigió diversas solicitudes consiguió que se le impusiese una pena similar a la de Daza y Sagarzurieta, conmutándose los diez años de presidio en Alhucemas sancionados para él inicialmente por destierro en Zaragoza y el pago de qui-

25 Causa de Estado instruida contra Pedro José Daza..., AHN, Consejos, legajo 6294, exp. 1 , f.

${ }_{26}$ Causa de Estado instruida contra Pedro José Daza..., AHN, Consejos, legajo 6294, exp. 1, f. 19r.

27 Causa de Estado instruida contra Pedro José Daza..., AHN, Consejos, legajo 6294, exp. 1, ff. 347v-349v. 
nientos duros de multa, según la propuesta del fiscal el 12 de diciembre de 1817, con lo que se conforma Fernando VII el 3 de marzo de $1818^{28}$.

Los asuntos que motivaron la revisión del periódico y la indagación sobre sus responsables fueron la defensa de la soberanía nacional, la libertad de imprenta y la Constitución, así como la decidida apuesta de no obedecer a Fernando VII hasta que jurase la Carta Magna que se aprecia en el cuaderno del 2 de mayo de $1814^{29}$.

\section{El Tribuno del Pueblo Español (Cádiz, 3-XI-1812/5-XI-1813 y Madrid, 1-II/1-IV-1814)}

El 28 de septiembre de 1814 se iniciaban las pesquisas sobre los editores de El Tribuno del Pueblo Español. Desde Madrid, José de Arteaga pedía que se recogiese una colección con todos sus números y que se tratase de averiguar quiénes eran sus autores. En los meses de octubre y noviembre se buscan ejemplares y se precisa quiénes se encontraban tras la redacción del papel. Resultan fundamentales para esto las palabras de Juan Domingo Villegas -regente de la imprenta Tormentaria en Cádiz-, que indica que en las dos épocas en las que vio la luz El Tribuno los redactores fueron: Álvaro Flórez Estrada y Narciso Rubio, en la primera, y estos dos, José Canga Argüelles y Juan Rico, en la segunda. El impresor también apunta que los números los firmaba Manuel Bertrán de Lis, dando fe de que se correspondían con los originales. Lo dicho por Villegas será ratificado por Rafael Calderón, encargado de escribir los originales para darlos a la imprenta ${ }^{30}$.

Se inicia así la investigación sobre sujetos implicados en la vida del impreso, del que el 16 de diciembre de 1814 Mariano Rodríguez de Olmedo remite una colección de 114 números en los que ha señalado aquello que considera peligroso, pues según dice aunque sus:

máximas antirreligiosas y antimonárquicas son bien manifiestas y claras, no es a la verdad tan desvergonzado y atrevido como lo fueron la Abeja, Redactor, Conciso, etc., pero el esfuerzo con que abulta cualquier defecto en los monarcas, la suma dependencia que quiere tengan estos del pueblo, las trabas ignominiosas que quiere poner a nuestro augusto soberano don Fernando, la avilantez con que habla de

28 Causa de Estado instruida contra Pedro José Daza..., AHN, Consejos, legajo 6294, exp. 1 ff. 475r-492r y 487r-490r.

29 Sobre este último aspecto véase SÁNCHEZ HITA, 13, Aix-en-Provence, 2016.

30 Causa de Estado instruida contra Juan Rico, Narciso Rubio y Álvaro Flórez Estrada, editores del periódico «El Tribuno Español», AHN, Consejos, legajo 6297, exp. II, ff.13v$17 \mathrm{v}$. El trabajo de la imprenta fue una de las cuestiones que preocupó a los redactores, como evidencia la existencia de un reglamento al respecto formado el 9 de julio de 1813, f. 32r-v. 
todo potentado, dan muy bien a entender su inclinación hacia la república o anarquía ${ }^{31}$.

Estas ideas son las que sustentan las preguntas lanzadas a los editores que pudieron ser apresados -Flórez Estrada había huido-, ante las que tratan de demostrar que jamás plantearon arrebatar el trono a Fernando VII o atacar su soberanía.

Los primeros en recibir una condena fueron el sacerdote Juan Rico y Narciso Rubio, para quienes el 1 de marzo de 1815 se solicitan diez años de reclusión en uno de los conventos más austeros de su orden — que será el de Nuestra Señora del Castañar, en la provincia de Castilla-, en el primer caso, y para Narciso Rubio se pide el destierro de la Corte y Sitios Reales y la ciudad de Valencia por espacio de ocho años veinte leguas de contorno. A Manuel Bertrán de Lis se le condena a pagar una multa en mil ducados, y a todos se les impone el pago de las costas. El 6 de marzo Fernando VII se conforma con la sentencia ${ }^{32}$.

Se sigue la causa contra Canga Argüelles y Álvaro Flórez, porque el primero tiene otra iniciada y el segundo no ha sido localizado. Para formar el proceso contra Flórez Estrada, se recurre a lo dicho por diversos testigos en la Sumaria General de Cádiz y se les pide que ratifiquen lo dicho; estos sitúan a Flórez Estrada como uno de los más activos liberales en la época de las Cortes y llegan a tildarlo de republicano. Por todo ello, el 12 de enero de 1816 es condenado a muerte y se solicita que sean confiscados todos sus bienes, mientras que el periódico debía quemarse públicamente. El 14 de enero Fernando VII aprueba la condena, pero precisa que no se queme el impreso por el momento para «no remover especies», algo que acaso parecía peligroso tratándose de uno de los periódicos «más subversivos e irreligiosos» de aquella época en opinión del fiscal ${ }^{33}$.

Canga Argüelles se encontraba preso desde el 10 de mayo de 1814 en el depósito de San Martín en Madrid y estaba siendo juzgado por otras causas relacionadas con las reuniones mantenidas en Cádiz por los liberales, actitud en las Cortes, etcétera, lo que hace menos presente en su caso el proceso contra $E l$ Tribuno. Acaba siendo condenado por Fernando VII a través del Decreto de 15 de diciembre de 1815 a ocho años en el castillo de Peñíscola, jubilado con la mitad de su sueldo y se le imposibilita el conseguir empleo alguno ${ }^{34}$.

31 Causa de Estado instruida contra Juan Rico..., AHN, Consejos, legajo 6297, exp. II, ff. 19r-v.

32 Causa de Estado instruida contra Juan Rico ..., AHN, Consejos, legajo 6297, exp. II, f. 124r. y 126r. La indicación del convento al que debe ser enviado se produce el 13 de marzo de 1815 y la firma Miguel Acevedo.

${ }_{33}$ Causa de Estado instruida contra Juan Rico..., AHN, Consejos, legajo 6297, exp. II, ff.272r-273v, y 268v.

34 VILLANUEVA, 1820: 502. 
Poco antes de tomar esta dura determinación contra Canga y Flórez, el monarca se muestra algo más magnánimo con Narciso Rubio, a quien el 21 de noviembre de 1815 se le conmuta el destierro por una multa de 200 ducados por año de condena ${ }^{35}$.

\section{El Ciudadano (Madrid, 1-VII/29-X-1813)}

El 14 de julio de 1814 comienza el juicio contra el equipo de El Ciudadano por las expresiones que figuran en sus primeros cuadernos, entre las que se destaca la contenida en la primera entrega donde se lee «el Rey no es nuestro señor, es nuestro jefe porque queremos, y de la manera que queremos que lo sea, y nada más $»^{36}$. Como de costumbre se recurre al impresor para averiguar quiénes lo redactaban y para tratar de obtener un juego del papel. En este caso Francisco Fernández, regente de la imprenta de Fuentenebro, indica que los editores eran cuatro, pero que no recuerda los datos concretos de uno de ellos, siendo los otros tres Manuel Merino, Francisco ${ }^{37}$ Sánchez Barbero - que eran los principales responsables-y el capellán del Refugio; añade además que se tiraron los treinta y cinco cuadernos que había entregado.

Ese mismo día declara Merino que sitúa como los encargados del periódico además de él mismo y Sánchez Barbero a José Rodríguez, cura del Refugio y fray José Canal, apuntando que los cuatro tenían la misma parte y que solamente a Sánchez Barbero se le tenía cierta consideración por haber sido el promotor de El Ciudadano por orden del jefe político - Joaquín García Domenech-38. La referencia hecha aquí al periódico como encargo de una autoridad superior va a ser un elemento repetido por los demás miembros del equipo, pues les servirá para avalar que actuaron de acuerdo con el Gobierno. En principio esta argumentación no surte efecto y Merino es conducido a la Real Cárcel de la Villa ${ }^{39}$. El 18 de julio vuelve a ser reclamado, para que precise qué contenidos redactó cada uno de ellos de entre aquellos que se consideraban afrentosos ${ }^{40}$.

35 Causa de Estado instruida contra Juan Rico..., AHN, Consejos, legajo 6297, exp. II, «Informe pedido por S. M. a la solicitud de don Narciso Rubio; sobre que se le conmute la pena de ocho años de destierro que sufre en pecunaria», ff. 19r-20r.

36 El Ciudadano, 1(Madrid, 1813): 4.

37 Citado en la declaración como Fulano, por lo recordar el nombre y llama José a Manuel Merino. Causa de Estado contra los editores del periódico titulado «El Ciudadano», por ciertos artículos aparecidos en dicha publicación, AHN, Consejos 6313, exp. 2, f. 6v.

38 Causa de Estado contra los editores del periódico titulado «El Ciudadano»... AHN, Consejos 6313, exp. 2, f. 8r.

39 Causa de Estado contra los editores del periódico titulado "El Ciudadano»..., AHN, Consejos 6313, exp. 2, f. 12r.

40 Causa de Estado contra los editores del periódico titulado «El Ciudadano»..., AHN, Consejos 6313, exp. 2, f. 22r-25r. 
El 16 de julio le toca el turno a Francisco Sánchez Barbero, que estaba preso en la real cárcel de la Corte por ser editor de El Conciso. Cuando se le comunica que se halla retenido por la publicación de El Ciudadano no duda en indicar quiénes fueron sus autores y en manifestar que el objetivo de la cabecera era sostener el sistema gubernamental y, aunque reconoce como propio el discurso del número uno, pese a que no lo era, y el del número 8 titulado «Patria» - aparecido antes en $\mathrm{El} \mathrm{Conciso-,} \mathrm{por} \mathrm{lo} \mathrm{general} \mathrm{indicará}$ que ignora la autoría de los artículos o fragmentos que le muestran y desmiente que su responsabilidad al frente del periódico fuese mayor a la de otros ${ }^{41}$.

El 20 de julio declara José Rodríguez, que manifiesta que cree estar preso por su participación en El Universal y no tarda en admitir su implicación en El Ciudadano, explicando además que al poco tiempo de pasar a Madrid, acabada la ocupación de la ciudad, recibió recado del jefe político de contribuir en la escritura de un periódico destinado a «rectificar la opinión pública», para cuya elaboración se contaba ya con los anteriores, a los que se sumaría el padre Canal, todos ellos con iguales responsabilidades en la redacción ${ }^{42}$. En las preguntas que el fiscal le dirige al cura del Refugio, se llega a especificar que el contenido de numerosos artículos - escritos por él o por otros- atenta contra la soberanía de Fernando VII, pues contribuían a democratizar la nación, lo que niega José Rodríguez apuntando que «recomendar la Constitución no tenía en él otro sentido que el de unir a los españoles durante la ausencia del Rey» ${ }^{43}$ y se ofrece a reparar los daños que con sus opiniones hubiese causado, pues actuó movido por el convencimiento de que los derechos del rey estaban preservados. Queda recluido en su casa, por lo que parece que sus palabras convencieron al fiscal. El 21 de julio fray José Canal, preso en el convento de San Felipe el Real, confirma todo lo dicho por los anteriores.

Estos testimonios comprometen al jefe político Joaquín García Domenech, a quien se interroga ese mismo día 21. Manifiesta que encargó la redacción del periódico por habérselo pedido así el Ministro de Gobernación de la Península cuando salió de Cádiz a Madrid, para fomentar «la ilustración pública, y singularmente la extensión de ideas verdaderamente patrióticas», para lo que recurrió a Sánchez Barbero, que indagaría qué otros sujetos podían elabo-

41 Por el momento no ha sido posible localizar la causa seguida contra El Conciso, que en principio había sido la que motivó el arresto de Sánchez Barbero. Causa de Estado contra los editores del periódico titulado «El Ciudadano»..., AHN, Consejos 6313, exp. 2, ff. 14r, 16r$17 \mathrm{v}, 19 \mathrm{v}, 21 \mathrm{v}$.

42 Causa de Estado contra los editores del periódico titulado «El Ciudadano»..., AHN, Consejos 6313, exp. 2, f. 26v-27r.

43 Causa de Estado contra los editores del periódico titulado «El Ciudadano»..., AHN, Consejos 6313, exp. 2, f. 30 r. 
rar junto a él un papel serio y ajeno a las «chocarrerías de algunos otros» ${ }^{44}$, siendo los responsables últimos de los gastos y beneficios los redactores.

En agosto los encausados vuelven a ser requeridos e introducen algunos cambios respecto a lo dicho sobre la responsabilidad en la composición de ciertos artículos; siendo clave el inserto en el primer cuaderno que resultó ser obra de Merino; así como el texto remitido que con el título de «¿Qué han hecho las Cortes?» se publica entre los números 18 y 22, del que al no conocerse al autor se responsabiliza a los editores. A partir de lo dicho por los periodistas se insiste en la gravedad de lo recogido en el primer cuaderno y en la paridad de ideas que muestran en este sentido Barbero y Merino, lo que lleva al fiscal a pedir el 30 de agosto «que se les imponga la pena de diez años de presidio a Puerto Rico con retención» ${ }^{45}$, mientras que en los casos de José Rodríguez y fray José de la Canal la acusación da por buena la reclusión sufrida hasta aquel día y se conforma con la actitud de respeto a Fernando VII. Por su parte, a García Domenech se le impone una multa de quinientos ducados y los costes mancomunados de la causa junto a los otros cuatro reos.

Como era de esperar Rodríguez y Canal se muestran de acuerdo con la sentencia el 22 de septiembre de 1814 — aunque acabarán siendo condenados por su participación en El Universal_ «6 ${ }^{46}$ pero no sucede lo mismo con Merino y Sánchez Barbero que nombrarán abogados — Juan de Dios Brieva y Vicente Francho Gutiérrez, respectivamente-, para armar su defensa en base a los méritos alcanzados durante la Guerra de la Independencia.

En el caso de Francisco Sánchez Barbero en sus apelaciones se incluyen las Odas relativas a los actuales acaecimientos (1808) en las que ataca a los franceses e intenta encender el patriotismo, destacándose la cuarta de ellas titulada «Proclamación a Fernando VII», así como los testimonios aportados por varios testigos que ratifican el compromiso de Sánchez Barbero con la causa de la patria en el inicio del conflicto, cuando fue apresado en Pamplona de donde logró escapar y establecerse en Cádiz, mostrando siempre lealtad al rey, a quien honró con unos versos ante su venida ${ }^{47}$.

De Merino se destaca que tomó las armas para defender Madrid al comenzar la guerra y que fue apresado por los franceses, que estuvieron a punto de fusilarlo, lo que le empuja a fugarse de la ciudad, no sin antes socorrer a otros

${ }^{44}$ Causa de Estado contra los editores del periódico titulado «El Ciudadano»..., AHN, Consejos 6313, exp. 2, f. 37v-38r.

45 Causa de Estado contra los editores del periódico titulado «El Ciudadano»..., AHN, Consejos 6313, exp. 2, f. 73r.

46 Causa de Estado contra los editores del periódico titulado «El Ciudadano»..., AHN, Consejos 6313, exp. 2, f. 89r-v.

47 Pueden verse al respecto los documentos contenidos en el segundo bloque de la Causa de Estado contra los editores del periódico titulado «El Ciudadano»..., AHN, Consejos 6313, exp. 2, (Probanza hecha por parte de Don Francisco Sánchez Barbero), ff. 1r-31v. 
presos. Se destaca que en todo momento ensalzó la figura de Fernando VII y condenó la perfidia de los franceses ${ }^{48}$.

Las alegaciones sirvieron para variar parcialmente la pena, pues con fecha de tres de diciembre de 1814 la Comisión castiga a Merino con «diez años de presidio en el Peñón, con retención, que no quebrante pena de la vida» y a Sánchez Barbero «a diez en el de Melilla con las mismas cualidades», siendo condenados todos a abonar las costas de la causa, en la que asimismo se establece que «se queme en la Plazuela de la Cebada en el sitio donde se ejecutan las sentencias un ejemplar del periódico titulado El Ciudadano por mano del ejecutor público». El 13 de marzo de 1815 Fernando VII se conforma con esta condena y para el 1 de abril se dispone la quema a las 11 de la mañana, con verdugo y pregonero ${ }^{49}$.

Un poco más tarde los hijos de Merino, Antonio y María, conseguirán que la sanción que se le impuso sea modificada, pues el 29 de marzo de 1815 solicitan que se cambie el lugar de reclusión por Málaga o Ceuta, pues desde el Peñón no puede procurar la subsistencia de ellos y su madre y que se aminore la pena, a lo que accede Fernando VII el 22 de junio permitiendo la reclusión en Ceuta ${ }^{50}$.

\section{El Universal (Madrid, 1-I/11-V-1814)}

El proceso a los autores de este periódico liberal se inicia por la denuncia hecha por varios militares, entre ellos el brigadier Juan Antonio Barutell y el coronel Antonio Solá, que califican de «atroz calumnia» el contenido del ejemplar del 6 de mayo de 1814 en el que se asegura que los oficiales del tercer ejército se han reunido para declararse protectores de la Constitución ${ }^{51}$. Ante esto el día 22 de mayo se pide que los editores sean arrestados con la mayor brevedad.

El 23 de mayo dicha orden pasa a los jueces de policía de Madrid y ese mismo día se interroga a Vicente de Ayta, que aporta la identidad y domicilio

48 Sobre Manuel Merino y su defensa véase Causa de Estado contra los editores del periódico titulado «El Ciudadano»..., AHN, Consejos 6313, exp. 2, (Probanza hecha por Don Manuel Merino), ff. 1r-22v.

49 Causa de Estado contra los editores del periódico titulado «El Ciudadano»..., AHN, Consejos 6313, exp. 2, ff. 104r y 105r-v y 109r.

50 Causa de Estado contra los editores del periódico titulado «El Ciudadano»..., AHN, Consejos 6313, exp. 2, ff. 121r y 126r.

51 El texto figura en la página 502. La denuncia en Causa de Estado contra Jacobo Villanova, Vicente de Ayta, José Rodríguez y José de la Canal, todos ellos editores y colaboradores del periódico llamado «El Universal», por la publicación en dicho periódico en 6 de mayo de 1814 de la noticia de que los oficiales del Tercer Ejército se declaran defensores de la Constitución, AHN, Consejos, legajo 6314, exp. 2, f. 2r. 
de los demás editores del periódico, que son: Jacobo Villanova, con la misma parte en El Universal que él, al que acompañaban otros dos redactores a los que pagaban un honorario mensual: José Rodríguez, capellán del Refugio y fray José de la Canal, que como se recoge arriba habían participado en la tirada de El Ciudadano. Señala que conserva todos los papeles de borradores y demás que se encuentran en casa de Villavona, lo que permite verificar que el texto denunciado fue obra de Canal y que contenía enmiendas de Villanova ${ }^{52}$.

El 24 de mayo Jacobo Villanova apunta lo mismo que Ayta respecto al resto de redactores, aunque en el caso de Ayta precisa que, si bien las producciones de todos eran iguales y se las comunicaban unos a otros, este por las ocupaciones de la imprenta no entraba en la parte literaria y solía encargarse de los asuntos económicos, las noticias y algunas contestaciones. Respecto al texto de la polémica, admite haber sido autor de las correcciones que se basaron en el original facilitado por un sujeto, cuyo nombre desconoce. El mismo día José Canal ratifica todo lo dicho por los anteriores y en relación con el texto del 6 mayo matiza que cuando extractó desde el original lo hizo «moderando algunas de las expresiones que contenía y omitiendo otras ${ }^{53}$.

Por su parte, José Rodríguez, cura de El Refugio, aunque coincide en la mayor parte de lo dicho con los demás redactores, no duda en mostrar la diferente actitud que adoptó tras la llegada de Fernando VII a Valencia cuando se retira de la empresa y previene:

\begin{abstract}
a sus compañeros sería del caso, hasta no saber las intenciones de S.M., guardar un profundo silencio en razón de opiniones políticas; añadiéndoles «Pues que el rey calla, las Cortes callan, y nosotros no deberemos abalanzarnos, ni aun bajo suposiciones arbitrarias, tal vez a corromper la opinión y propagar la discordia en daño del Rey y de la Patria: por lo que a mí hace me retiro desde este momento, pues nada trabajaré que directa o indirectamente convida con un orden de cosas que solo ofrecen oscuridad ${ }^{54}$.
\end{abstract}

Tras las consultas se establece que Ayta pase a la Cárcel de la Corte, Villanova a la Real de la Villa, Canal al convento de San Felipe y, en vista de las palabras de Rodríguez, se le permite que guarde cárcel en El Refugio. El 26 de mayo se pasa el informe a Fernando VII y se determina que se analice completo el periódico, por lo que Ayta nombra a Antonio Picolomini como testigo del registro de las papeletas y documentos relacionados con la vida de

52 Causa de Estado contra Jacobo Villanova ..., AHN, Consejos, legajo 6314, exp. 2, ff. $8 \mathrm{v}-11 \mathrm{v}$. Se incluye la papeleta escrita a mano en la causa f. 12r.

53 Causa de Estado contra Jacobo Villanova ..., AHN, Consejos, legajo 6314, exp. 2, f. 17r.

54 Causa de Estado contra Jacobo Villanova ..., AHN, Consejos, legajo 6314, exp. 2, f. 18 r. 
El Universal55. El 28 de mayo Pedro Macanaz informa de que el rey en virtud de las noticias que le han hecho llegar, que resultan ser las del proceso por el contenido del papel del 6 de mayo, establece que se condene a Villanova a seis años de reclusión en uno de los presidios de África y a Canal al mismo tiempo de reclusión en uno de los conventos más rígidos de su orden; añade además que se publique la sentencia en la Gaceta de Madrid junto con los documentos de la solicitud y queja hecha por los oficiales del tercer ejército y las respuestas de los procesados, lo que se verificó en la Gaceta del 14 de junio de $1814^{56}$.

La determinación del rey desconcierta a Alcalá Galiano, pues omite el que se proceda a formar causa contra el periódico como la Comisión había determinado. Eleva por ello una consulta y el 31 de mayo se indica que, en efecto, debe analizarse todo el impreso, por lo que los encausados permanecerán en los lugares en los que estaban y no en los de la pena. Así las cosas, José Rodríguez solicita que se le amplíe la carcelaria a Madrid y arrabales y José de la Canal se esfuerza en demostrar que su papel con respecto al número de 6 de mayo fue el de un mero reseñador de lo escrito por otro y que lo hizo porque los dueños de la empresa se lo pidieron, por lo que, equiparándose a los oficiales de caja, pide que se imputen las críticas a estos y no a él. Lejos de obtener lo pedido su situación se complicaría, pues el 15 de julio se insiste en su retención por estar implicados también en la tirada de El Ciudadano ${ }^{57}$.

En estas fechas, el volumen de las averiguaciones realizadas por la Comisión de Policía hace que se faculte a nuevos jueces para continuar los procesos, en lo que respecta a El Universal el encargado será en adelante Félix Ruiz Aguilar.

En agosto vuelve a tomarse declaración a los procesados, siendo sus palabras especialmente interesantes para entender cómo se componía el periódico, qué parte tenía cada uno y qué otros sujetos estaban implicados en el impreso. Esto último hará que, a diferencia de lo habitual en otras causas, en esta acaben siendo castigadas con distintas penas personas no implicadas directamente en la empresa.

En lo que respecta al funcionamiento del periódico, Villanova, Canal, Ayta y Rodríguez precisan que por norma general cada ejemplar se componía de doce artículos - aunque en el prospecto se indicaba que serían dieciocho-, y que el primero tomaba parte en la redacción de los decretos de las Cortes y en las variedades aunque no habitualmente; el segundo extractaba los impresos

55 Causa de Estado contra Jacobo Villanova ..., AHN, Consejos, legajo 6314, exp. 2, f. $20 \mathrm{v}-21 \mathrm{r}$.

56 Causa de Estado contra Jacobo Villanova ..., AHN, Consejos, legajo 6314, exp. 2, f. 23r-v. Gaceta de Madrid (Madrid, 14-VI-1814): 655-656.

57 Causa de Estado contra Jacobo Villanova..., AHN, Consejos, legajo 6314, exp. 2, ff. 29r, 31r-32r y 40r. 
enviados desde provincias, componía algún texto de variedades y poesías de asuntos místicos; el tercero se hacía cargo de la caja de la imprenta y la corrección de pruebas, mientras que el cuarto se dedicó a las variedades y a la parte literaria hasta que el rey entró a Valencia, cuando se retiró prácticamente de la redacción. Todos ellos mencionan que llegaban noticias de sujetos ajenos a la redacción y Ayta dirá que a algunos se les daba como gratificación el periódico y que otros recibían una pequeña cantidad de dinero ${ }^{58}$.

Como consecuencia de las explicaciones de los redactores y a partir del cotejo de nombres conservados en el juego del periódico de la imprenta, serán requeridos el autor de El Amante de la Libertad Civil —identificado por el impresor Eusebio Álvarez como Francisco Rodríguez Isla, huido-59, Landaburu, Juan Corradi, José Hevia, Juan Siles y Manuel Abella y Gasco, Antillón - fallecido cuando se le reclama-, Francisco Borja Sánchez y Francisco Doncel. Por diferentes razones no todos son localizados, pero sí llegan a declarar Landaburu, a quien el 10 de septiembre se le interroga en relación al texto que festejaba la abolición de la Inquisición que había remitido y sobre el que expone que con él quiso aportar una prueba de adhesión al Gobierno y sus determinaciones; Corradi que el 11 de septiembre indica que recibía 50 reales diarios por aportar el extracto de las sesiones de Cortes; José Hevia que precisa que cobraba ochocientos reales mensuales por el extracto de los papeles extranjeros ese mismo día, y Juan Siles que tras ser reclamado a las autoridades de Montoro, donde ejercía como profesor de Medicina, señala el 6 de octubre que remitió textos en elogio a las Cortes, sin pensar que estos pudiesen considerarse una ofensa a Fernando VII ${ }^{60}$.

A partir de todos estos testimonios el 10 de octubre de 1814 se dicta sentencia y se condena a Jacobo Villanova a un total de diez años de presidio en África, pues a los cuatro que recibe por la causa completa por su labor en $E l$ Universal se suman los seis de la que se siguió por el artículo del 6 de mayo; José de la Canal deberá pasar diez años de reclusión en el convento de El Risco (Ávila) que resulta ser el más austero de su orden'61; José Rodríguez será

58 Las declaraciones de cada uno de los redactores y el reconocimiento de los artículos firmados por ellos o por otros a los que fueron sometidos en esta fase del juicio pueden verse en Causa de Estado contra Jacobo Villanova ..., AHN, Consejos, legajo 6314, exp. 2: Villanova, 2 de agosto de 1814, ff. 43r-46r y 3 de agosto de 1814, ff. 64r-66r; Canal, 2 de agosto de 1814, ff. 46r-49r y 3 de agosto de 1814, ff. 66r-68r; Ayta, 2 de agosto de 1814, ff. 49r-52r y 26 de agosto de 1814, ff. 68r-70v y Rodríguez, 28 de agosto de 1814, ff. 70v-72v.

59 Aunque se reclama al autor del impreso en varias ocasiones, no llega a localizarse y tampoco parece que fuese juzgado en ausencia.

60 Causa de Estado contra Jacobo Villanova ..., AHN, Consejos, legajo 6314, exp. 2, ff. $73 \mathrm{r}-110 \mathrm{v}$.

61 Según recoge Sainz de Baranda, 1850: 10, es liberado hacia mayo de 1815 por mediación de una persona muy allegada a Fernando VII. 
enviado al paraje que determine el vicario de su orden por espacio de seis meses, que será el convento de Capuchinos de la Villa de Cubas más una multa de doscientos ducados; Vicente Ayta es multado con seiscientos ducados; igualmente se condena a los cuatro a pagar mancomunadamente las costas del proceso. De entre los colaboradores del periódico recibió sanción Juan Antonio Siles, que fue desterrado dos años de la Corte y Sitios Reales en veinte leguas en contorno y multado con seiscientos ducados y las costas de su proceso; José Hevia fue apercibido de que en lo sucesivo no diese motivos de sospecha con su conducta y a Landaburu y Corradi se les continuarían otras averiguaciones. El 22 de octubre el rey aprueba las penas ${ }^{62}$.

En los meses y años siguientes los editores no dudarán en enviar testimonios de su fidelidad a Fernando VII para conseguir que se aminoren las penas o que se admitan aplazamientos en el pago de las multas, a lo que se accede más o menos de manera general. De entre las diferentes alegaciones llama la atención la de Villanova, quien había recibido una pena mayor por serlo también su trabajo en el diario, quien recurre a la mediación del Obispo de Orense, para que primero se le conmute la pena de prisión por destierro a lo que se accede el 6 de marzo de 1815, para más tarde, el 7 de diciembre de 1815, y en atención a que el resto de responsables ya se encuentra libre pedir su absolución a lo que se accede el 19 de junio de $1816^{63}$. Previamente, el 26 de noviembre de 1814, Villanova ya había solicitado que se le cambiase la pena aportando como prueba de su respecto a Fernando VII un escrito suyo publicado en El Universal n ${ }^{\circ} 101$ (11-IV-1814), que acaso pudo satisfacer el ego del monarca, pues concluye con las siguientes palabras: «iOh Fernando feliz! Delicias del género humano llamaron a Tito, y tú naciste para ser las delicias del pueblo español» ${ }^{64}$.

62 Causa de Estado contra Jacobo Villanova..., AHN, Consejos, legajo 6314, exp. 2, ff. $115 \mathrm{r}-116 \mathrm{r}$, para la condena general y para los matices sobre destinos y costas ff. $119 \mathrm{r}-134 \mathrm{v}$. En el caso concreto de Juan Corradi, acabará siendo condenado el 21 de julio de 1815 a salir fuera del reino con toda su familia, lo que lo llevó a Perpiñán y más tarde a París, GIL NOVALES, 2010; Landaburu resultó condenado a cuatro años, los dos primeros en el castillo de Alicante y los otros de destierro de la Corte y sitios reales veinte leguas en contorno, además de en cada caso al pago de las costas de las causas seguidas contra ellos y otros, aunque según recoge GIL NOVALES, 2010, es liberado el 14 de mayo de 1815 y el 25 presenta un escrito de adhesión al rey absoluto.

63 Los documentos con las solicitudes de Villanova se localizan en dos carpetas que siguen a la causa general con los títulos de: «Permuta en destierro de la pena de presidio impuesta a Jacobo Villanova» y «Real Orden de informe a la solicitud de Jacobo Villanova comprendida en la causa seguida a los editores del periódico titulado El Universal».

64 El Universal 101, (Madrid, 1814): 401. 


\section{NOTICIAS INDIRECTAS DE CONDENAS Y PROCESOS DE LA COMISIÓN DE CAU- SAS DE ESTADO ${ }^{65}$}

\section{El Diario Mercantil de Cádiz (1-XI-1802/15-III-1814) de José Lacroix, barón de la Bruère 66}

José María de Lacroix ponía fin a la tirada de su veterano Diario Mercantil el 15 de marzo de 1814. Trataba de escapar así de las posibles represalias que por su publicación podrían derivarse $y$, acaso para desviar un tanto la atención de sus contenidos, se proponía sacar en corto plazo un impreso rotulado Amenidades Literarias anunciado en el último número del Diario Mercantil, destinado principalmente a mujeres y cuyo prospecto vio la luz a finales de marzo, según recoge El Redactor General no 85 (25-III-1814), aunque no llegó a estamparse ${ }^{67}$.

Esta prevención le sirvió de poco. El hecho de que se viese señalado como uno de los liberales más activos en la época de las Cortes, según consta en las comunicaciones de Molle en la Sumaria General, por ser su casa punto habitual de encuentro de los representantes de dicha ideología ${ }^{68}$, así como los artículos del Diario Mercantil ${ }^{69}$ fueron motivos más que suficientes para detener-

65 Para completar este apartado nos hemos valido principalmente de las minutas con las condenas dadas por la Comisión de Causas de Estado, conservadas en el Expediente general de la Comisión de Causas de Estado, AHN, Consejos, legajo 6298, exp. 5; así como del Decreto de 15 de diciembre de 1815. También se han consultado los años 1814-1816 de Gaceta de Madrid y el Diario de Madrid, junto a la época en Madrid de El procurador General del Rey y de la Nación, que arrojan por lo general poca luz sobre las causas y las condenas.

66 Los datos relativos al arresto del barón de la Bruère en Ceuta proceden del capítulo destinado a establecer su biografía en la tesis doctoral de ROMÁN LÓPEZ, 2016. Sobre la figura como empresario periodista de De la Bruére, pueden verse los trabajos de DOMERGUE, 1981; LARRIBA, 4, Aix-en-Provence, 2007 y ROMÁN LÓPEZ, 9, Aix-en-Provence, 2015.

67 En el Mercurio Gaditano no 147 (12-X-1814) se anuncia su publicación de las Amenidades Literarias desde el 14 de octubre en adelante, pero no parece que llegase a salir.

68 Sumaria General de Cádiz, AHN, Consejos, legajo 6302, exp. 1, f. 13v.

69 Por algunos de ellos fue juzgado Manuel Antonio González (El Turonense) el 18 de octubre de 1819 con la siguiente sentencia: «en seis años de reclusión en el Castillo de Peñíscola, sin que pasados pueda salir de él sin expresa licencia de Su Majestad, se le priva del empleo de oficial primero de la contaduría de crédito público de Oviedo, y de obtener cualquiera otro público, se le condena en las costas y se le apercibe que si en adelante diese motivo a iguales procedimientos será castigado con todo el rigor de las leyes», el 20 de octubre el rey aprobaba la sentencia. (Causa de Estado instruida contra Manuel Antonio González, vecino de Oviedo, oficial que fue de la Contaduría General de Consolidación de Vales, acusado de haber publicado varios artículos subversivos en el Diario Mercantil de Cádiz y el Redactor General de España, bajo el seudónimo de "El Turonense» y de haber borrado con lodo varios reales decretos de mayo de 1814, AHN, Consejos, legajo 6300, exp. 1, f. 86r. 
lo el 28 de noviembre de 1814 y enviarlo a Ceuta el 13 de diciembre donde debía permanecer diez años y para pedir la quema del periódico desde el día de instalación de las Cortes hasta el 4 de mayo.

Desde Ceuta, Lacroix se esfuerza por hacer valer sus méritos militares para obtener el perdón del monarca. En una carta dirigida a Fernando VII el 20 de mayo de 1815 dice ser un mero testaferro en el Diario de las ideas de otros y señala que fue la necesidad la que hizo que buscase en el periodismo un medio de sustento, pues había perdido sus bienes con la Revolución Francesa y además con el inicio de la Guerra de la Independencia había dejado de cobrar el sueldo que como teniente disperso recibía desde $1792^{70}$. Esta argumentación se repite en otras misivas y hace que acabe por concedérsele un indulto parcial el 9 de septiembre de 1815 que le permite instalarse en el Campo de Gibraltar; una enfermedad demora su marcha hasta mediados de 1816 cuando llega a Algeciras, desde allí el 19 de junio de 1816 reclama poder pasar a Cádiz o que se le conceda la agregación a la plaza de Málaga, además del pago de los atrasos. La respuesta a esta petición o no llegó o no se ha conservado, sea como sea, poco después el barón debió morir pues en 1819 el título había pasado a su hijo José María de La croix y Amarillas ${ }^{71}$.

\section{Abeja Española (Cádiz, 12-IX-1812/31-VIII-1813) y Duende de los Ca- fés (Cádiz, 1-VIII-1813/14-V-1814)}

Hasta la fecha no ha sido posible localizar la causa realizada a estos periódicos, de los que el 27 de octubre de 1814 se solicitó que se recogiesen colecciones y se iniciaron las interpelaciones a los impresores para conocer quién se encontraba tras su redacción, según consta en los documentos del proceso a El Redactor General72.

Uno de los primeros interrogados fue Ramón Howe - regente de la Imprenta Patriótica en esas fechas - ${ }^{73}$ quien precisa que en el tiempo en que se publicó la Abeja Española el encargado del taller era Ramón Verges, ya fallecido, y que componían la redacción Mejía Lequerica, muerto el 28 de noviembre de 1813, y Manuel Alzáibar, que tenía causa abierta por su participa-

70 Esta afirmación es cierta solo en parte, pues desde 1790 la participación de José Lacroix en diferentes empresas periodísticas fue una constante.

71 AGMS, Sección 1 ${ }^{a}$, legajo C-3824 cit. en Román López, 2016.

72 Causa de Estado instruida contra Pedro José Daza..., AHN, Consejos, legajo 6294, segundo ramo, f. $1 \mathrm{r}-\mathrm{v}$.

73 Nicolás Gómez de Requena y Domingo Closas, fueron otros de los interrogados y aportaron además ejemplares de la publicación. Véase SÁNCHEZ HITA, 13, Aix-enProvence, 2016. 
ción en El Redactor General y que se encontraba huido ${ }^{74}$. No se incluye entre los responsables del periódico a Bartolomé José Gallardo, pese a que en el proceso iniciado contra él por su conducta política, Francisco José de Molle lo situó como autor de artículos de la $A b e j a$ en su etapa madrileña y de $E l$ Redactor General de Cádiz ${ }^{75}$. Fue, no obstante, el uso de la Biblioteca de Cortes - de la que era director- como espacio de reunión de los liberales y el contenido del Diccionario crítico-burlesco, los elementos que provocaron que fuese finalmente condenado el 7 de noviembre de 1815 a la pena de muerte y a la confiscación de sus bienes, tras ser juzgado en ausencia, pues en mayo de 1814 había huido vía Lisboa hacia Londres ${ }^{76}$.

A pesar de la no localización del proceso contra la Abeja Española a partir de los documentos del seguido a El Redactor General es posible saber que fueron la defensa de la libertad de expresión, las Cortes o las críticas a la Inquisición y a los serviles los asuntos que se destacaron como perniciosos ${ }^{77}$.

Algo similar a lo que sucede con la Abeja ocurre con El Duende de los Cafés, cuyo editor Juan Jacinto María López, huido a Portugal, acabaría siendo condenado en ausencia el 12 de abril de 1815 a la pena de muerte, confiscación de bienes, al tiempo que se pedía la quema del periódico. Las críticas a la iglesia y los serviles, realizadas en clave literaria a través de supuestas visitas de duendes y brujas a los lugares de reunión de estos, así como las prevenciones que se muestran en algunos artículos ante las verdaderas intenciones de Fernando VII en su vuelta al trono, fueron los temas sobre los que se llama la atención en el proceso de formación de causa ${ }^{78}$.

Ahora bien, el caso de El Duende de los Cafés ilustra en gran medida cómo la persecución a los liberales no se detuvo con el dictado de sentencias, pues la posible localización de los fugados fue una cuestión que siguió preocupando. En lo que se refiere a Juan Jacinto María López podemos saber que el 9 de febrero de 1819 se reactiva su búsqueda tras la denuncia de Miguel Grau, que lo sitúa en Villa Real de San Antonio con el nombre de Cecilio López, precisando que desde 1817 se había dejado ver por la Higuerita

74 Causa de Estado instruida contra Pedro José Daza..., AHN, Consejos, legajo 6294, segundo ramo, f. 5r. y 17v. Los papeles del proceso contra la Abeja se unieron a la causa de Alzáibar, sin embargo, no parecen haberse conservado en esta.

75 La declaración de Molle se produce con fecha de 14 de mayo de 1815. Causa de Estado instruida contra Bartolomé José Gallardo, AHN, Consejos, legajo 6301, exp. 1, f. 80r

76 Causa de Estado instruida contra Bartolomé José Gallardo, AHN, Consejos, legajo 6301, exp. 1, fol. 90r. Sobre el proceso seguido contra Gallardo y las implicaciones que este tuvo para sus familiares y amigos puede verse PÉREZ VIDAL, 2015: 151-166.

77 Esta información se desprende de los pasajes subrayados en el proceso seguido contra El Redactor General, tal y como recoge más ampliamente SÁNCHEZ HITA, 13, Aix-enProvence, 2016.

78 Remitimos para ampliar este punto a SÁNCHEZ HITA, 13, Aix-en-Provence, 2016. 
(actual Isla Cristina, Huelva) debido a su amistad con el alcalde primero José Alejandro Rivera ${ }^{79}$. Esto hace que desde marzo de 1819 hasta febrero de 1820 se activen los mecanismos para apresarlo, intentando averiguar además quiénes habían sido los cómplices en su huida, para ello se requisa la correspondencia que recibía desde Cádiz y Madrid y se solicita al Alcalde de Ayamonte que colabore en su captura. Nada se consigue, pues alguien debió alertar a Juan López y varió nuevamente su identidad. Desconocemos qué hubiese ocurrido en el caso de haber resultado hallado, aunque es seguro que se le impondría una condena de prisión y no de muerte, pues es lo habitual en todas las causas.

\section{El Conciso (Cádiz, 24-VIII-1810/24-XII-1813 y Madrid, 16-I/11-V-1814)}

Otro de los procesos no localizados entre los papeles de la Comisión de Causas de Estado es el de los redactores de El Conciso, que fue uno de los títulos incluidos en el listado de 4 de mayo junto a El Redactor General y que se cita en varias ocasiones en la causa contra El Ciudadano, cuando se estudia la participación en este de Francisco Sánchez Barbero. Pese a no haberse hallado el proceso es posible conocer cuál fue la pena impuesta a sus redactores, pues, el 15 de diciembre de 1815 Fernando VII haciendo uso de su poder absoluto establecía para Manuel Pérez Soriano y Ramajo y Francisco Sánchez Barbero una condena de diez años de reclusión en Melilla, como se recoge en el Diario Gaditano no 158 (19-II-1821).

\section{El Redactor General de España (Madrid, 1-XI-1813/11-V-1814)}

El 9 de noviembre de 1814 la Comisión de Causas de Estado dictaba sentencia a Jacinto Manrique, Bernabé García, Camilo Gamboa por su papel en el citado periódico y se les impusieron las siguientes penas: Manrique debía permanecer diez años en el presidio del arsenal de Cartagena de Levante tras los que no podría salir sin licencia del monarca; Bernabé García permanecería diez años en Melilla en los mismos términos que el anterior, y a ambos se les privaba de sus empleos y cátedras y se les condenaba a los costes del proceso, salvo a los originados por Gamboa que correría con la parte de los suyos. Más tarde a Fernández Sardinó, huido a Londres, que había sido coeditor del periódico y que además había tomado parte activa en la edición de varios papeles públicos durante la Guerra de la Independencia, entre ellos el polémico

79 Juan López, Duende de los Cafés, AHN, Consejos, legajo 11390, exp. 2, f. 20v. 
Robespierre Español (21-III-1811/VIII-1812), se le condena a muerte de horca, confiscación de sus bienes y pago de los costes del proceso el 3 de marzo de 1815. Se añade que el papel se queme en la plazuela de la Cebada ${ }^{80}$.

\section{La Abeja Madrileña (Madrid, 16-I/7-V-1814)}

Del proceso contra los sujetos que tiraban este papel público solo ha sido posible obtener noticias sobre las penas impuestas a Antonio Villarino y José Regato, que se citan como sus editores y que fueron condenados el 26 de noviembre de 1814 a la horca, a los costes de la causa y a la confiscación de sus bienes, ordenándose la quema del periódico en la plazuela de la Cebada.

\section{El Amigo de las Leyes (Madrid, 2-X-1812/1-XII-1812 y 15-II/3-V-1814)}

Mejor suerte que los anteriores corrieron Francisco Javier Barra el editor del impreso y José Lucio Pérez, que lo acompañaba en la tarea, que fueron condenados el 3 de septiembre de 1814 al pago de los costes de sus procesos y al abono de 50 ducados de multa.

\section{A MODO DE CONCLUSIÓN}

A través de las páginas precedentes ha quedado dibujada la persecución a la que se vieron sometidos numerosos periodistas liberales que, por haber sostenido con sus empresas un régimen constitucional que limitaba los poderes del rey, se consideraron enemigos de Fernando VII y cuyas producciones se tuvieron por el verdadero cuerpo del delito de sus atentados contra el poder absoluto, de ahí que se analicen los contenidos de los títulos considerados sospechosos, lo que hacía necesario en primer lugar la consecución de colecciones - aquí los impresores ocupan un papel clave como delatores- $\mathrm{y}$, tras

80 Asimismo en función de un breve documento conservado en el Expediente general de la Comisión de Causas de Estado, AHN, legajo 6298, exp. 5, (carpeta 10), es posible saber que con motivo de la inclusión en el periódico de una suscripción para reunir fondos para los indigentes que tuviesen que reclamar infracciones de la Constitución, y que parece que acabó por invertirse en viandas para la tertulia del conde de Noblejas —investigado en otras causas junto a su hermano Ramón Chaves y Agustín Goicoechea-, terminaron siendo procesados Alfonso Pérez, Joaquín García Domenech, Martín Goicochea, José Señán y Mariano Valero y Arteta. Mientras que se reclama a otros ausentes como Fernández Sardinó, Manuel María Losada, Eusebio Manuel de la Mota y Domingo Villamil. 
ella, dan comienzo diferentes procesos en los que editores y colaboradores son recluidos e interrogados minuciosamente.

De entre los encausados ninguno queda libre de algún tipo de sanción. En el mejor de los casos esta consiste en una multa de entre 50 y 600 ducados, pero lo más frecuente es que sean enviados a prisión a Ceuta, Melilla, al Peñón, a las cárceles de diferentes ciudades o sufran el destierro de su lugar de residencia habitual, de la Corte y de los sitios reales, cuando no son eclesiásticos y, cuando lo son, se suele determinar que se recluyan en los conventos más rigurosos de sus órdenes; penas estas que se acompañaban, además, del abono de los costes de las causas y con multas que rara vez podían pagar con facilidad. Ahora bien, conviene matizar que tras recusar las condenas, empleando para este fin algún que otro elogioso escrito a favor de Fernando VII o haciendo gala de las actuaciones heroicas protagonizadas durante la Guerra de la Independencia, muchas de las sanciones fueron aminoradas o se aceptó el cumplimiento de los arrestos en lugares más cómodos, como se hace con Manuel Merino, Pérez Soriano y Ramajo o Sánchez Barbero; muy puntualmente se cambiaron años de arresto por multa como se hizo con Narciso Rubio y, en otros pocos casos, se llega a conceder el indulto como ocurre con Jacobo Villanova, el barón de la Bruère o fray José de la Canal. Frente a esto nunca se eliminan los costes de los procesos, abonados mancomunadamente por cada uno de los encausados, o las diferentes sanciones, aunque se amplía el plazo para su pago.

Por su parte, los fugados son sistemáticamente condenados a muerte y se embargaban sus bienes, pues la huida se convierte en un claro agravante y por sí sola se considera testimonio de sus afrentas contra el Borbón, aunque se deja abierta la posibilidad de que se defiendan si son localizados. En el caso de estos últimos suele determinarse la quema de los papeles públicos que habían editado - como ocurre con El Duende de los Cafés o La Abeja Madrile$\tilde{n} a$ - . Algo igualmente habitual en el caso de aquellos títulos marcados por su liberalismo acérrimo como El Conciso, El Ciudadano o El Redactor General de España y que también se hizo extensivo a otros más moderados como el Diario Mercantil de Cádiz. Sorprende en este punto el proceder seguido con El Tribuno del Pueblo Español cuya quema se aplaza por deseos del propio monarca ante el temor de que pudiese ser contraproducente por remover las especies contenidas en él. Lamentablemente no parecen haber quedado testimonios de estas quemas en los periódicos estampados en aquellas fechas, acaso porque no se les dio excesiva publicidad - aunque por el proceso contra El Ciudadano es posible conocer que era preciso disponer de verdugo y pregonero para ejecutar las penas - o porque los medios para anunciarlas pudieron ser otros como los pasquines o algún suelto inserto en la Gaceta de Madrid no hallado por el momento, tal y como sucede con la relación de las sentencias, que como indicó en su día Fernández Marín se incluyeron como pliegos sueltos en la Gaceta de Madrid, y que no parecen haberse conservado 
o no han sido halladas en las colecciones consultadas ${ }^{81}$. Sea como sea, serían muchos los que se alegrarían de la quema de los periódicos liberales citados en este estudio y aun de otros muchos, basta recorrer las páginas de El Procurador General del Rey y de la Nación (Madrid, 16-I-1814/al menos hasta el 27-V-1815), tras la vuelta al trono de Fernando VII, donde en diversos artículos se llama a quemar determinados impresos, tal y como se hizo con la Constitución en no pocos lugares; sirva como ejemplo el artículo del cuaderno del 16 de agosto en el que J. M. M. sugiere recoger y quemar «al Redactor, Diario Mercantil, Conciso, Abeja, etc., y demás calaña subversiva» ${ }^{82}$.

Todas estas actuaciones, realizadas entre mayo de 1814 y diciembre de 1815 , servían para aplacar posibles sublevaciones contra Fernando VII que actuaba con rigor contra quienes según su opinión habían puesto en duda su soberanía defendiendo que esta residía en la nación; aunque andando en el tiempo y acaso porque las alegaciones de los editores lograron satisfacer su ego o porque quiso mostrarse magnánimo acabó disminuyendo los castigos.

Asimismo, en los procesos contra los responsables de las diferentes cabeceras, se aprecia cómo en esta búsqueda de culpables los impresores van a jugar un papel clave pues, sin más opciones que responder a las preguntas, revelan quiénes integran los equipos de redacción y facilitan los periódicos cuando los tienen, lo que posibilita la formación de los procesos al sumar estos documentos a las palabras de aquellos sujetos que declararon contra quienes consideraban liberales al inicio de la instrucción de las causas.

Por otro lado, de manera colateral a los procesos, en los documentos estudiados queda representada la profesionalización que en el ejercicio del periodismo se había producido ya en 1810 , cuando es frecuente que sean varios sujetos los que se encarguen de la redacción de los diferentes títulos, con misiones diferenciadas o que se pague a colaboradores externos para el envío de noticias o la elaboración de ciertos contenidos, sobre todo en aquellos títulos con periodicidad diaria, valga de ejemplo el caso de Juan Corradi que remite los extractos de las sesiones de las Cortes a El Redactor General y a El Universal; del mismo modo se suele producir el trasvase de redactores de unas cabeceras a otras, como sucede con José Rodríguez y José de la Canal que pasan de El Ciudadano a El Universal. Todos estos hechos evidencian que el periodismo se había convertido en un buen medio para ganarse la vida, además de en una vía para influir en la política; esto hará que, pese a las negativas consecuencias que el retorno al absolutismo tuvo en 1814 para muchos gaceteros, en 1820 vuelvan a la palestra viejos títulos como El Redactor General, que acaso con más precauciones que en la primera época constitucio-

81 FERNÁNDEZ MARÍN, 1900: 195, aunque precisa que parece que por lo general la publicación oficial se cuidó de no difundir los delitos o las faltas de los juzgados, 1900: 216.

82 El Procurador General del Rey y de la Nación 77, (Madrid, 16-VIII-1814): 633. 
nal, sirvió nuevamente de soporte a un régimen político que se esforzaba por segunda vez por desterrar el absolutismo.

\begin{tabular}{|c|c|}
\hline \multicolumn{2}{|r|}{ ANEXO } \\
\hline PERIÓDICOS & PERIODISTAS Y CONDENAS \\
\hline $\begin{array}{l}\text { Semanario Patriótico (Ma- } \\
\text { drid, 1-IX/24-XI-1808; Sevi- } \\
\text { lla, 4-V/31-VIII-1809 y Cá- } \\
\text { diz, 22-XI-1810/19-III-1812) }\end{array}$ & $\begin{array}{l}\text { Manuel José Quintana. Condena: costes mancomu- } \\
\text { nados del proceso y seis años de reclusión en Pam- } \\
\text { plona (Decreto } 15 \text { de diciembre de } 1815 \text { ). } \\
\text { Eugenio de Tapia. Condena: costes mancomunados } \\
\text { del proceso, } 22 \text { de agosto de } 1814 \text {. Multa de } 500 \text { du- } \\
\text { cados, } 2 \text { de diciembre de } 1815 \text {. } \\
\text { José Rebollo. Condena: costes mancomunados del } \\
\text { proceso, } 22 \text { de agosto de } 1814 \text {. Multa de } 500 \text { ducados, } \\
2 \text { de diciembre de } 1815 \text {. } \\
\text { Juan Álvarez Guerra. Condena: costes mancomuna- } \\
\text { dos del proceso y ocho años de destierro en Ceuta } \\
\text { (Decreto de } 15 \text { de diciembre de } 1815 \text { ). } \\
\text { *No procesados: José María Blanco, Isidoro Anti- } \\
\text { llón y Joaquín Abaitúa (Exiliados o huídos). }\end{array}$ \\
\hline $\begin{array}{l}\text { El Redactor General (15-VI- } \\
1811 / 18-V-1814)\end{array}$ & $\begin{array}{l}\text { Pedro José Daza. Condena: pago de dos mil duros y } \\
\text { los costes del juicio, } 8 \text { de noviembre de } 1815 \text {. } \\
\text { José Joaquín de Sagarzurieta. Condena: multa de } \\
\text { quinientos duros y costes del juicio, } 8 \text { de noviembre } \\
\text { de } 1815 \text {. } \\
\text { José Manuel Fernández de los Senderos. Fugado en } \\
\text { febrero de } 1815 \text {. Condena en ausencia: diez años de } \\
\text { presidio en el Peñón, } 8 \text { de noviembre de } 1815 \text {. } \\
\text { Manuel de Alzáibar. Procesado en rebeldía el } 29 \text { de } \\
\text { diciembre de } 1814 \text {, condenado a diez años de presidio } \\
\text { en Alhucemas, } 8 \text { de noviembre de } 1815 \text {. En diciembre } \\
\text { de } 1817 \text { se le conmuta la pena por la misma que a } \\
\text { Sagarzurieta y destierro de Zaragoza. } \\
* \text { No juzgados: José Redondo y Julián Villalba. }\end{array}$ \\
\hline $\begin{array}{l}\text { El Tribuno del Pueblo Espa- } \\
\text { ñol (Cádiz, 3-XI-1812/5-XI- } \\
\text { 1813 y Madrid, 1-II/1-IV- } \\
\text { 1814). }\end{array}$ & $\begin{array}{l}\text { Álvaro Flórez Estrada. Fugado. Condena: pena de } \\
\text { muerte y confiscación de bienes, } 12 \text { de enero de } 1816 \text {. } \\
\text { José Canga Argüelles. Condena: ocho años de reclu- } \\
\text { sión en el castillo de Peñíscola (Decreto de } 15 \text { de } \\
\text { diciembre de 1815). } \\
\text { Narciso Rubio. Condena: ocho años de destierro de } \\
\text { la Corte, Sitios Reales y la ciudad de Valencia, } 1 \text { de } \\
\text { marzo de } 1815 \text {. El } 21 \text { de noviembre se conmuta la } \\
\text { pena de destierro por el pago de } 200 \text { ducados por año } \\
\text { de condena. }\end{array}$ \\
\hline
\end{tabular}




\begin{tabular}{|c|c|}
\hline & $\begin{array}{l}\text { Juan Rico. Condena: diez años de reclusión en un } \\
\text { convento, } 1 \text { de marzo de } 1815 \text {. } \\
\text { Manuel Beltrán Lis. Condena: multa de mil ducados, } \\
1 \text { de marzo de } 1815 \text {. } \\
\text { * Se pide la quema del periódico, pero Fernando VII la } \\
\text { descarta en aquellos momentos para evitar remover } \\
\text { especies. }\end{array}$ \\
\hline $\begin{array}{l}\text { El Ciudadano (Madrid, 1- } \\
\text { VII/29-X-1813) }\end{array}$ & $\begin{array}{l}\text { Manuel Merino. Condena: diez años de presidio en } \\
\text { Puerto Rico con retención, } 30 \text { de agosto de } 1814 \text {; se } \\
\text { modifica por reclusión en el Peñón, } 3 \text { de diciembre de } \\
\text { 1814. El } 22 \text { de junio de } 1815 \text { se permite que la reclu- } \\
\text { sión sea en Ceuta. } \\
\text { Francisco Sánchez Barbero. Condena: diez años de } \\
\text { presidio en Puerto Rico con retención, } 30 \text { de agosto de } \\
1814 \text {; se modifica por reclusión en Melilla, } 3 \text { de di- } \\
\text { ciembre de } 1814 \text {. } \\
\text { José Rodríguez. Condena: prisión sufrida durante el } \\
\text { proceso, } 30 \text { de agosto de } 1814 \text {. } \\
\text { Fray José Canal. Condena: prisión sufrida durante el } \\
\text { proceso, } 30 \text { de agosto de } 1814 \text {. } \\
\text { Joaquín García Domenech (promotor). Condena: } \\
\text { multa de } 500 \text { ducados, prisión sufrida durante el pro- } \\
\text { ceso, } 30 \text { de agosto de } 1814 \text {. }\end{array}$ \\
\hline $\begin{array}{l}\text { El Universal (Madrid, 1-I/11- } \\
\text { V-1814) }\end{array}$ & $\begin{array}{l}\text { Vicente de Ayta. Condena: multa de seiscientos du- } \\
\text { cados, } 10 \text { de octubre de } 1814 \text {. } \\
\text { Jacobo Villanova. Condena: diez años de presidio en } \\
\text { África, } 10 \text { de octubre de } 1814 \text {. Logra ser absuelto el } \\
19 \text { de junio de } 1816 \text {. } \\
\text { José Rodríguez. Condena: reclusión en el convento } \\
\text { de Capuchinos de la Villa de Cubas y multa de dos- } \\
\text { cientos ducados, } 10 \text { de octubre de } 1814 \text {. } \\
\text { Fray José de la Canal. Condena: diez años de reclu- } \\
\text { sión en el convento de El Risco (Ávila), } 10 \text { de octubre } \\
\text { de } 1814 \text {. Será absuelto antes de mayo de } 1815 \text {. } \\
\text { Juan Antonio Siles (colaborador). Condena: multa de } \\
\text { seiscientos ducados y destierro por dos años de la } \\
\text { Corte y Sitios Reales, } 10 \text { de octubre de } 1814 \text {. }\end{array}$ \\
\hline $\begin{array}{l}\text { Diario Mercantil de Cádiz (1- } \\
\text { XI-1802/15-III-1814) }\end{array}$ & $\begin{array}{l}\text { José Lacroix, barón de la Bruère. Condena: diez } \\
\text { años de reclusión en Ceuta ( } 13 \text { de diciembre de 1814). } \\
\text { Indulto: } 9 \text { de septiembre de } 1815 \text {. } \\
\text { *Quema del periódico desde la instalación de las Cor- } \\
\text { tes al } 4 \text { de mayo. }\end{array}$ \\
\hline $\begin{array}{l}\text { Abeja Española }(12-\mathrm{IX}- \\
1812 / 31-\mathrm{VIII}-1813) \\
\text { Fuentes indirectas }\end{array}$ & $\begin{array}{l}\text { Bartolomé José Gallardo. Fugado. Condena: pena de } \\
\text { muerte y confiscación de bienes ( } 7 \text { de noviembre de } \\
\text { 1815). }\end{array}$ \\
\hline
\end{tabular}




\begin{tabular}{|c|c|}
\hline & $\begin{array}{l}\text { José Mejía Lequerica. No juzgado. Muerto el } 28 \text { de } \\
\text { noviembre de } 1813 \text {. } \\
\text { Manuel María Alzáibar. Huido. Juzgado por su } \\
\text { participación en El Redactor General. }\end{array}$ \\
\hline $\begin{array}{l}\text { El Duende de los Cafés }(1- \\
\text { VIII-1813/14-V-1814) } \\
\text { Fuentes indirectas }\end{array}$ & $\begin{array}{l}\text { Juan Jacinto María López. Huido. Condena: pena } \\
\text { de muerte y confiscación de bienes. } \\
\text { *Quema del periódico. }\end{array}$ \\
\hline $\begin{array}{l}\text { El Conciso (Cádiz, 24-VIII- } \\
\text { 1810/24-XII-1813 y Madrid, } \\
\text { 16-I/11-V-1814) } \\
\text { Fuentes indirectas }\end{array}$ & $\begin{array}{l}\text { Francisco Sánchez Barbero. Condena: diez años de } \\
\text { reclusión en Melilla. } \\
\text { Manuel Pérez Soriano y Ramajo. Condena: diez } \\
\text { años de reclusión en el Peñón, luego pasa a Melilla. } \\
\text { *Quema del periódico. }\end{array}$ \\
\hline $\begin{array}{l}\text { El Redactor General de Es- } \\
\text { paña }(1-\mathrm{XI}-1813 / 11-\mathrm{V}-1814) \\
\text { Fuentes indirectas }\end{array}$ & $\begin{array}{l}\text { Jacinto Manrique. Condena: diez años en el presidio } \\
\text { del arsenal de Cartagena de Levante, } 9 \text { de noviembre } \\
\text { de } 1814 \text {. } \\
\text { Bernabé García. Condena: diez años en Melilla, } 9 \text { de } \\
\text { noviembre de } 1814 \text {. } \\
\text { Camilo Gamboa. Condena: costes del proceso y } \\
\text { apercibimiento de no volver a implicarse en empresas } \\
\text { semejantes en el futuro, } 9 \text { de noviembre de } 1814 \text {. } \\
\text { Pedro Pascasio Fernández Sardinó. Huido. Conde- } \\
\text { na: a muerte por horca, confiscación de bienes y pago } \\
\text { de los costes, } 3 \text { de marzo de } 1815 \text {. } \\
\text { *Quema del periódico. }\end{array}$ \\
\hline $\begin{array}{l}\text { La Abeja Madrileña }(16-\mathrm{I} / 7- \\
\text { V-1814) } \\
\text { Fuentes indirectas }\end{array}$ & $\begin{array}{l}\text { Antonio Villarino. Huido. Condena: a muerte por } \\
\text { horca, confiscación de bienes y pago de los costes } \\
\text { José Regato. Huido. Condena: a muerte por horca, } \\
\text { confiscación de bienes y pago de los costes. } \\
\text { *Quema del periódico. }\end{array}$ \\
\hline $\begin{array}{l}\text { El Amigo de las Leyes (Ma- } \\
\text { drid, 2-X-1812/1-XII-1812 y } \\
\text { 15-II/3-V-1814) } \\
\text { Fuentes indirectas }\end{array}$ & $\begin{array}{l}\text { Francisco Javier Barra. Condena: } 50 \text { ducados de } \\
\text { multa y costes del proceso, } 3 \text { de septiembre de } 1814 \text {. } \\
\text { José Lucio Pérez. } 50 \text { ducados de multa y costes del } \\
\text { proceso, } 3 \text { de septiembre de } 1814 \text {. }\end{array}$ \\
\hline
\end{tabular}

* Parte del contenido de esta tabla procede de Sánchez Hita, 13 (Aix-en-Provence, 2016), aquí se ha completado y ampliado la información.

\section{Biblografía}

Álvarez Coca, María Jesús, «Invasión francesa, gobierno intruso. Los fondos de la Guerra de la Independencia en el Archivo Histórico Nacional», Cuadernos de Historia Moderna, [en línea]. 37 (2012). Disponible en: http://dx.doi.org/10.5209/ rev_CHMO.2012.v37.39236. 
Checa Godoy, Antonio, La prensa española durante la Guerra de la Independencia (1808-1814), Cádiz, Quorum Libros, 2009.

Domergue, Lucienne, Tres calas en la censura dieciochesca (Cadalso, Rousseau y Prensa periódica), Toulouse, Institut d'Etudes Hispaniques et Hispanoaméricaines de 1'Université de Toulouse-Le Mirail, 1981.

Durán López, Fernando (ed.), Manuel José Quintana. Memoria del Cádiz de las Cortes, Cádiz, Servicio de Publicaciones de la Universidad de Cádiz, 2003.

Fernández Marín, Manuel, Derecho parlamentario español, t. III, Madrid, Imprenta de los hijos de J. A. García, 1900.

Gil Novales, Alberto, Prensa, Guerra y Revolución: Los periódicos españoles durante la Guerra de la Independencia, Madrid, Consejo Superior de Investigaciones Científicas-Doce Calles, 2009.

Gil Novales, Alberto, Diccionario biográfico de España (1808-1833), Madrid, Fundación Mapfre, 2010.

La Parra López, Emilio, «La restauración de Fernando VII en 1814», Historia Constitucional [en línea], 15 (2014). Disponible en: http://www.historiaconstitucional. com/index.php/historiaconstitucional/article/view/402/361 [consultado el 20 de abril de 2016].

Larriba, Elisabel, «Le baron de la Bruère: un patron de presse au temps des «Don Quichotte du monde philosophique», El Argonauta Español [en línea], 4 (2007). Disponible en http://argonauta.revues.org/1248 [consultado el 14 de mayo de 1814].

Pérez Vidal, Alejandro, «La condena a muerte de Bartolomé José Gallardo en 1815», en Marieta Cantos Casenave y Alberto Ramós Santana (eds.), La represión absolutista y el exilio, Cádiz, 2015; 151-166.

Rodríguez Castillo, Miguel, «Los papeles reservados de Fernando VII; Identificación, análisis y propuesta de descripción normalizada», Revista General de Información y Documentación, [en línea], vol. 23-1 (2013). Disponible en: http://dx.doi.org/10.5209/rev_RGID.2013.v23.n1.41454

Román López, María, «José de la Croix, barón de la Bruère. Desde Valencia a su Diario Histórico y Político de Sevilla (1790-1793)», El Argonauta Español [en línea], 9 (2012). Disponible en: http://argonauta.revues.org/1357 [consultado el 14 de mayo de 1814].

Román López, María, Las empresas periodísticas del Barón de la Bruère. Valencia, Sevilla y Cádiz (1790-1814), Cádiz, 2016.

Sainz de Baranda, Pedro, Ensayo histórico de la vida literaria del maestro fray José de la Canal, de la orden de San Agustín, director de la Academia de la historia y continuador de la España Sagrada, Madrid, Imprenta de la Real Academia de la Historia, 1850.

Sánchez Hita, Beatriz, Los periódicos del Cádiz de la Guerra de la Independencia (1808-1814). Catálogo comentado, Cádiz, Diputación Provincial de Cádiz, 2008.

Sánchez Hita, Beatriz, «El Redactor General (1811-1814) de Pedro José Daza o cómo hacer un gran periódico en el Cádiz de las Cortes», Cuadernos de Ilustración 
y Romanticismo, [en línea]. 16 (2010). Disponible en: http://revistas.uca.es/ index.php/cir/article/view/176 [consultado el 14 de mayo de 2016].

Sánchez Hita, Beatriz, «La restauración del absolutismo y el obligado silencio de la prensa liberal. Los casos de El Redactor General (15-VI-1811/18-V-1814), la Abeja Española (12-IX-1812/31-VIII-1813) y El Duende de los Cafés (1-VIII1813/14-V-1814)», El Argonauta Español, [en línea], 13 (2016). Disponible en: https://argonauta.revues.org/2379 [consultado el 20 de mayo de 2016].

Villanueva, Joaquín Lorenzo, Apuntes sobre el arresto de los vocales de Cortes, ejecutado en mayo de 1814, Madrid, Imprenta de Don Diego García Campoy y Compañía, 1820.

Recibido: $26 / 05 / 2016$

Aprobado: 07/03/2017 